\title{
Exogenous nucleosides accelerate differentiation of rat intestinal epithelial cells
}

\author{
Jose María Vieites ${ }^{1}$, Raúl de la Torre ${ }^{1}$, María del Carmen Ramírez ${ }^{1}$, María Isabel Torres ${ }^{2}$, Antonio \\ Sánchez-Pozo ${ }^{1}$, Angel Gil ${ }^{1}$ and Antonio Suárez ${ }^{1 *}$ \\ ${ }^{1}$ Department of Biochemistry and Molecular Biology II, School of Pharmacy, University of Granada, Granada, 18071, Spain \\ ${ }^{2}$ Department of Experimental Biology, University of Jaen, Jaen, Spain
}

(Received 27 March 2007 - Revised 25 June 2007 - Accepted 20 August 2007)

Several studies have reported differing data on the effect of exogenous nucleosides and nucleotides on the proliferation and differentiation in various intestinal cell lines and explants. To study whether exogenous nucleosides modulate intestinal cell differentiation, IEC-6 cells were differentiated in the presence or absence of a nucleoside mixture (cytidine, uridine, guanosine and inosine, $30 \mu \mathrm{M}$ each), and the concentrations of nucleoside derivatives were determined by HPLC. Cell differentiation was assessed by electron microscopy, alkaline phosphatase activity and Rnd3 gene expression. The present results showed that uridine, guanosine and inosine were cleared from culture media (up to 32, 63 and $100 \%$ in proliferating cells, and 31, 80 and $94 \%$ in differentiated cells, respectively) whereas cytidine concentrations increased. Differentiation of IEC-6 cells was associated with a significant increase in intracellular nucleotide concentrations. Clearance of nucleosides correlated with a significant increase in the intracellular nucleotide pool in proliferating and differentiated IEC-6 cells. Intracellular guanosine nucleotides increased 2.5- and 5-fold in nucleoside-supplemented proliferating and differentiated cells, respectively. At $24 \mathrm{~h}$, nucleoside-supplemented differentiated IEC-6 cells had significantly higher energy charge and GTP levels than non-supplemented ones. These modifications paralleled changes in cell differentiation as indicated by increased alkaline phosphatase activity, prolonged microvilli formation and accelerated down-regulation of Rnd3 gene expression. The present findings suggest that exogenous nucleosides were selectively taken up by IEC-6 cells, increased the intracellular nucleotide pool, GTP and energy charge, and favoured cell morphological and functional changes during differentiation.

Differentiation: Intestinal epithelial cells: Exogenous nucleosides: Intracellular nucleotides

Nucleotides (NT) are the building blocks of DNA and RNA and are normal components of the human diet and the nonprotein-nitrogen fraction of milk ${ }^{1}$. Nucleosides (NS) and NT are not considered essential since cells possess biochemical pathways for their de novo synthesis and salvage. However, in certain circumstances, NT may become conditionally essential nutrients that modulate different biological processes, such as lipid metabolism and immune function, and have an important role in cell proliferation, maturation, and apoptosis ${ }^{2-4}$. Besides, dietary NT have been shown to enhance gut recovery after different kinds of intestinal injury ${ }^{5-9}$. Because of the biochemical and trophochemical properties of dietary NT and NS, the European Commission has permitted some of them to be used as a supplement in the manufacture of infant and follow-on formulas.

Although NT deficiencies have not been related to any particular disease, various studies have assessed the effect of exogenous NT and NS on the intracellular pool of NT and on cell proliferation and differentiation. In hepatic cells, our group showed that exogenous NS were actively incorporated by hepatocytes and stimulated hepatocyte proliferation and expression of $c$-myc, $h$-ras genes and $\alpha$-fetoprotein ${ }^{10,11}$. Gil et $a{ }^{12}{ }^{12}$ recently showed that intestinal explants hydrolyse RNA to NT, and NT to NS that were efficiently incorporated into intestinal cells, except for cytidine. Reports on the effect of NT in intestinal cell proliferation and differentiation are contradictory. Sato et al. ${ }^{13}$ reported that a 10:1:1:1:1 CMPAMP-UMP-IMP-GMP mixture enhanced proliferation, sucrase and maltase activities in IEC-6 cells but not in Caco- 2 cells. In the same line, addition of NT (AMP, CMP, UMP, IMP, GMP) to a glutamine-free medium stimulated intestinal cell proliferation and increased alkaline phosphatase and sucrose-isomaltase activities in differentiated cells ${ }^{14}$. However, Boza et al. ${ }^{15}$ showed that the proliferative effect of NT on Caco- 2 cells was associated with the presence of glutamine in cell culture medium. Moreover, Tanaka et al. ${ }^{16}$ and Chen et al. ${ }^{17}$ observed that AMP supplementation decreased cellular proliferation and increased apoptosis in organ cultures and IEC-6 cells, respectively.

The goal of the present study was to reconcile the conflicting data published on the effect of NS on intestinal cells. The aim was to test the hypothesis that exogenous NS are taken up

Abbreviations: cDNA, first-strand complementary DNA; D - N, differentiated IEC-6 cells; D + N, differentiated IEC-6 cells grown with exogenous nucleosides; NS, nucleosides; NT, nucleotides; P - N, proliferating IEC-6 cells; P + N, proliferating IEC-6 cells grown with exogenous nucleosides.

* Corresponding author: Dr Antonio Suárez, fax +34 958248960, email asuarez@ugr.es 
and modify the concentrations of intracellular NT and the energy charge with effects on the morphological, functional and gene expression changes associated to cell differentiation. Overall, these data would determine whether selective NS uptake by intestinal cells alter the intracellular NT pool, thereby enhancing the differentiation on enterocytes. For this purpose, we used IEC-6 cells that undergo differentiation when grown on an extracellular protein matrix. IEC-6 cells were grown in the presence or absence of an inosine-guanosine-cytidine-uridine supplement at physiologic levels (30 $\mu \mathrm{M}$ each, a concentration selected to match NS concentrations in human milk, which range from 0.5 to $37 \mu \mathrm{M})^{18}$.

\section{Materials and methods}

\section{Materials}

Plastic culture ware was purchased from Nunc (Roskilde, Denmark). Cell culture medium (Dulbecco's modified Eagle's medium), trypsin, insulin, NS and NT were from Sigma Aldrich (St. Louis, MO, USA). SuperScript II, RNase Out, Trizol, L-glutamine, penicillin/streptomycin, fetal bovine serum and PBS were from Invitrogen (Carlsbad, CA, USA). $\left[\alpha-{ }^{32} \mathrm{P}\right] \mathrm{dCTP}$, Matrigel and dispase were purchased from Beckton Dickinson (Bedford, MA, USA). DNase I FPLCpure and TaqGold polymerase were from Amersham Pharmacia Biotech (Piscataway, NJ, USA). NIH Scion Image Beta 4.0.2 software (Scion Corporation, MD, USA) was used to quantify band intensity.

\section{Cell culture}

IEC-6 cell line was obtained from the American Type Culture Collection (Rockville, MD, USA) and was used between passages 20 and 25 in most experiments. A stock culture of IEC-6 was maintained using Dulbecco's modified Eagle's medium with $4.5 \mathrm{~g} / \mathrm{l}$ glucose, $10 \%$ fetal bovine serum, bovine insulin $(0 \cdot 1 \mathrm{U} / \mathrm{ml})$, penicillin/streptomycin and L-glutamine $(0 \cdot 6 \mathrm{~g} / \mathrm{l})$. The stock was passaged twice a week and fed three times a week.

In order to determine the effects of NS on cell proliferation and differentiation, IEC- 6 cells $\left(5 \times 10^{5}\right)$ were plated on $35 \mathrm{~mm}$ dishes coated with a thin layer of Matrigel. Media were supplemented with or without NS (cytidine, uridine, guanosine, inosine; $30 \mu \mathrm{M}$ each). The culture media were replaced with fresh NS every $12 \mathrm{~h}$. Cells were recovered from Matrigel by using dispase according to manufacturer's instructions.

\section{Transmission electron microscopy studies}

IEC-6 cells were grown on $3.0 \mu \mathrm{m}$ pore size Transwell-clear polyester membranes precoated with Matrigel, or on $3.0 \mu \mathrm{m}$ Transwell-COL type I and III collagen-coated membranes (Corning, Cultek, Spain). At 12 and $24 \mathrm{~h}$, monolayers were washed and fixed in $2.5 \%$ glutaraldehyde in cacodylate buffer $(0.1 \mathrm{M}, \mathrm{pH} 7 \cdot 3)$ and post-fixed in $1 \%$ osmium tetroxide. Monolayers were then dehydrated in ethanol and embedded in Epon 812 resin. Ultrathin sections $(50 \mathrm{~nm})$ were contrasted with uranyl acetate and lead citrate and examined under a Zeiss 902 transmission electron microscope.

\section{HPLC analysis of nucleosides and nucleotides}

NS present in culture media were separated and quantified by means of an ion-exchange HPLC method with some changes ${ }^{19}$. Briefly, media were recovered using a syringe and filtered through a $0.45 \mu \mathrm{m}$ filter to eliminate cell debris. Cleared media $(40 \mu \mathrm{l})$ were injected into the chromatograph. Two mobile phases were used: (1) $0 \cdot 1 \mathrm{M}$-potassium acetate, $\mathrm{pH}$ 4.5, 2 mM-hexasulphonic acid and $1 \%$ acetonitrile; and (2) $0.1 \mathrm{M}$-potassium acid, $\mathrm{pH} 4.5,2 \mathrm{~mm}$-hexasulphonic acid and $6 \%$ acetonitrile. NS were identified and quantified at $254 \mathrm{~nm}$ and compared with HPLC standards.

NT intracellular pools were analysed by using a HPLC $\operatorname{method}^{20}$. Briefly, cells were rinsed with PBS and frozen using liquid nitrogen to avoid NT degradation. Cells were then treated with percloric acid and incubated for $45 \mathrm{~min}$ to precipitate proteins. Supernatants were neutralized with potassium hydroxide, cooled, centrifuged and filtered. Cleared supernatants $(60 \mu \mathrm{l})$ were injected into the chromatograph. Two mobile phases were used: (1) $0.2 \mathrm{M}$-ammonium phosphate, $0 \cdot 1 \mathrm{M}$-triethanolamine, $\mathrm{pH}$ 6; and (2) $0 \cdot 2 \mathrm{M}$-ammonium phosphate, $0 \cdot 1 \mathrm{M}$-triethanolamine, $\mathrm{pH} 6$, and $15 \%$ acetonitrile. NT were identified and quantified at $254 \mathrm{~nm}$ and compared with HPLC standards.

\section{Enzyme activities}

Alkaline phosphatase (EC 3.1.3.1) activity was measured on crude cell homogenates using a spectrophotometric method based on the use of $p$-nitrophenylphosphate, which is transformed to phosphate and $p$-nitrophenol. The latter is a coloured compound that can be measured at $405 \mathrm{~nm}^{21}$. Units were expressed per milligram protein. The protein concentration was determined by the bicinchoninic acid method, using bovine albumin serum as standard ${ }^{22}$.

\section{$R N A$ extraction and reverse transcription-PCR}

Total RNA was extracted from cells grown on $35 \mathrm{~mm}$ dishes using Trizol according to the manufacturer's instructions. In order to avoid contamination by DNA, total RNA was treated with DNase I. The reaction took place at $37^{\circ} \mathrm{C}$ for $30 \mathrm{~min}$. Finally, RNA was extracted using phenol-chloroform and precipitated with sodium acetate and ethanol. The pellet was washed with $70 \%$ ethanol and stored dry at $-80^{\circ} \mathrm{C}$. Firststrand complementary DNA (cDNA) was synthesized with $0.1 \mu \mathrm{g}$ DNase-treated RNA and $0.5 \mu \mathrm{g}$ oligo-dT $_{16}$ in $20 \mu \mathrm{l}$ of a solution containing $1 \times$ first-strand buffer, $10 \mathrm{mmol} / \mathrm{l}$ dithiothreitol, $500 \mu \mathrm{mol} / 1$ each dNTP and $200 \mathrm{U}$ Moloney murine leukaemia virus RT. PCR reactions were carried out with primers for sucrase-isomaltase cDNA amplification forward primer, 5'-CAGAACACCACTGGTCTGAG-3'; reverse primer, 5'-TGGTTGTCATCTGCAGCAAC-3'). Glyceraldehyde-3-phosphate dehydrogenase was used as an internal control of a 'housekeeping' gene which was amplified with a forward primer $\left(5^{\prime}\right.$-TAAAGGGCATCCTGGGCT- $\left.3^{\prime}\right)$ and a reverse primer $\left(5^{\prime}\right.$-TTACTC CTTGGAGGCCATG-3'). PCR reactions were performed in the same set with an Applied Biosystems DNA thermal cycler model 9700 as follows: an initial denaturing for $5 \mathrm{~min}$ at $94^{\circ} \mathrm{C}$; forty cycles: $94^{\circ} \mathrm{C}$ for $30 \mathrm{~s}, 55^{\circ} \mathrm{C}$ for $30 \mathrm{~s}$ and $72^{\circ} \mathrm{C}$ for $30 \mathrm{~s}$; final extension at $72^{\circ} \mathrm{C}$ for $1 \mathrm{~min}$. 
DNA synthesis was resolved by standard agarose gel electrophoresis.

\section{Northern blot analysis}

A total of $10 \mathrm{mg}$ of denatured RNA was loaded per lane in a formaldehyde-1\% agarose gel, electrophoresed, transferred to nylon filters, and fixed with a UV crosslinker. The integrity of each sample was confirmed by staining the RNA with ethidium bromide. Filters were sequentially hybridized with a Rnd3 $\left[\alpha-{ }^{32} \mathrm{P}\right] \mathrm{dCTP}-$ labelled cDNA probe, stripped and hybridized with a $\left[\alpha-{ }^{32} \mathrm{P}\right] \mathrm{dCTP}$-labelled rat glyceraldehyde3-phosphate dehydrogenase cDNA probe to validate Northern blot results.

\section{Statistical analysis}

Results are means and their standard errors $(n$ 3). Since data were not normally distributed, comparisons between different groups were assessed by non-parametric tests. Mean comparisons between independent groups were calculated using the Mann-Whitney $U$-test. Mean comparisons within a group for different times were done using a Wilcoxon test for paired samples. Differences with $P<0 \cdot 05$ were considered significant. Data were analysed using the Statistical Package for Social Sciences software (SPSS Inc., Chicago, IL, USA).

\section{Results}

\section{Uptake of nucleosides by IEC-6 cells}

The time course of exogenous NS clearance in medium was determined. The culture media were replaced with fresh NS (30 $\mu \mathrm{M}$ each) every $12 \mathrm{~h}$. The present results show that uridine and purine NS were taken up by IEC-6 cells (Table 1). Purine NS were cleared at higher rates than pyrimidine NS. The clearance rate of uridine concentrations was similar in proliferating and differentiated cells, the values decreasing to $69 \%$ of the initial concentration at $12 \mathrm{~h}$ and remaining at that level at 24 and $48 \mathrm{~h}$. Guanosine was initially taken up by differentiated cells at a higher rate than proliferating cells although the contrary was observed at $48 \mathrm{~h}$. Inosine was the NS with the highest clearance rate in IEC- 6 cells. In proliferating cells, inosine was completely cleared from culture media at 24 and $48 \mathrm{~h}$. At all time-points, cytidine concentrations were higher than the dose in culture media $(30 \mu \mathrm{M})$ in proliferating and differentiated cells. No uric acid was detectable in culture media.

\section{Effects of nucleosides on the morphology of differentiated IEC-6 cells}

Exogenous NS did not change the external morphology of proliferating or differentiated IEC-6 cells. Intestinal cells grown on Matrigel showed a polarized morphology, typical of differentiated intestinal cells, with presence of microvilli at the apical pole. Interestingly, the addition of NS had a positive effect on the maturation of intestinal cells. Differentiated IEC-6 cells supplemented with NS $(D+N)$ showed more microvilli on their surface than did non-supplemented differentiated IEC-6 cells $(\mathrm{D}-\mathrm{N})$, and microvilli were still observed at $24 \mathrm{~h}$ in $\mathrm{D}+\mathrm{N}$ but not $\mathrm{D}-\mathrm{N}$ cells (Fig. 1). At $48 \mathrm{~h}$, no difference between $\mathrm{D}+\mathrm{N}$ and $\mathrm{D}-\mathrm{N}$ cells was observed (data not shown).

\section{Intracellular pool of nucleotides in IEC-6 cells}

Intracellular TMP, GDP and UDP were not detectable by HPLC analysis in proliferating IEC-6 cells. Thymidine NT, GDP and uridine diphosphoglucose were not detectable in differentiated cells. Except for TTP, concentrations of intracellular NT decreased from 12 to $24 \mathrm{~h}$ in proliferating IEC-6 cells $(\mathrm{P}-\mathrm{N})$ and in proliferating cells supplemented with NS $(\mathrm{P}+\mathrm{N}$; Table 2). The differentiation state resulted in an increase in the pool of intracellular NT in comparison with the proliferating state.

Addition of NS significantly changed the concentrations of intracellular NT in proliferating and differentiated cells. At 12 and $24 \mathrm{~h}$, concentrations of intracellular NT and total intracellular NT were significantly higher in $\mathrm{D}+\mathrm{N} v$. D $-\mathrm{N}$ cells $(P<0.05)$ with the exception of AMP and CMP. Intracellular IMP was detectable only in $\mathrm{D}+\mathrm{N}$ cells. Interestingly, the pool of guanosine NT was 5.0-fold higher in $\mathrm{D}+\mathrm{N}$ cells than in $\mathrm{D}-\mathrm{N}$ cells and 2.4-fold higher in $\mathrm{P}+\mathrm{N} v . \mathrm{P}-\mathrm{N}$ cells, and these differences were significant. Although intracellular ATP did not change, the GTP levels and energy charge were significantly higher in $\mathrm{D}+\mathrm{N} v$. $\mathrm{D}-\mathrm{N}$ cells (Fig. 2). It is noteworthy that intracellular NT levels in $\mathrm{D}+\mathrm{N}$ cells at $12 \mathrm{~h}$ were similar to or higher than levels in $\mathrm{D}-\mathrm{N}$ cells at $24 \mathrm{~h}$.

Table 1. Nucleoside concentrations in media of proliferating and differentiated IEC- 6 cells $†$ (Mean values with their standard errors for three determinations)

\begin{tabular}{|c|c|c|c|c|c|c|c|c|c|c|c|c|}
\hline & \multicolumn{6}{|c|}{ Proliferating cells (mm) } & \multicolumn{6}{|c|}{ Differentiated cells (mm) } \\
\hline & \multicolumn{2}{|c|}{$12 \mathrm{~h}$} & \multicolumn{2}{|c|}{$24 \mathrm{~h}$} & \multicolumn{2}{|c|}{$48 \mathrm{~h}$} & \multicolumn{2}{|c|}{$12 \mathrm{~h}$} & \multicolumn{2}{|c|}{$24 \mathrm{~h}$} & \multicolumn{2}{|c|}{$48 \mathrm{~h}$} \\
\hline & Mean & SE & Mean & SE & Mean & SE & Mean & SE & Mean & SE & Mean & SE \\
\hline Cytidine & $50 \cdot 9$ & $1 \cdot 4$ & $35 \cdot 7$ & $3 \cdot 1$ & $36 \cdot 9$ & 1.6 & $37 \cdot 6^{\star}$ & 1.6 & $40 \cdot 6$ & 0.4 & 39.9 & $1 \cdot 1$ \\
\hline Uridine & $20 \cdot 4$ & 0.1 & $21 \cdot 1$ & 1.0 & $21 \cdot 8$ & 0.2 & $20 \cdot 8$ & 1.0 & 21.4 & 0.5 & $24 \cdot 3^{*}$ & 0.1 \\
\hline Guanosine & $11 \cdot 2$ & 0.6 & $5 \cdot 3$ & 0.3 & $6 \cdot 8$ & 0.1 & $6 \cdot 1^{*}$ & $2 \cdot 5$ & $6 \cdot 3$ & 0.8 & $12 \cdot 0^{*}$ & 0.4 \\
\hline Inosine & $1 \cdot 3$ & 0.2 & - & - & - & - & $2 \cdot 1$ & 0.4 & $1 \cdot 7^{*}$ & 0.1 & $6 \cdot 2^{*}$ & 1.5 \\
\hline
\end{tabular}

Mean values were significantly different from those of proliferating cells at the same time-point: ${ }^{*} P<0.05$.

† IEC- 6 cells were cultured in media supplemented with uridine, cytidine, guanosine and inosine ( $30 \mu \mathrm{M}$ each). 
(A)

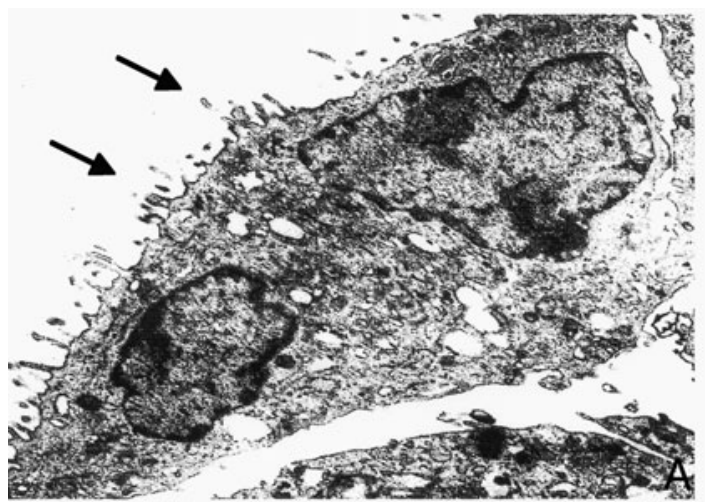

(B)

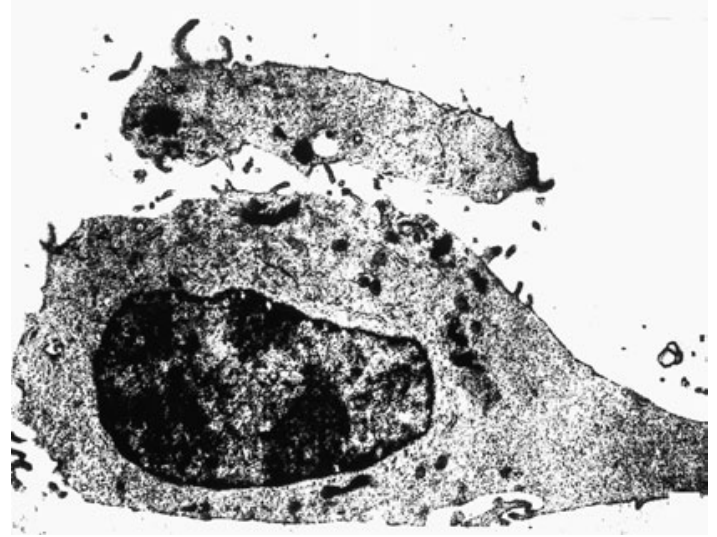

Fig. 1. Transmission electron micrographs of differentiated IEC-6 cells grown with (A) or without (B) nucleosides. Cell media was supplemented with uridine, cytidine, guanosine and inosine (30 $\mu \mathrm{m}$ each). $\rightarrow$, Microvilli.

\section{Alkaline phosphatase activity in IEC-6 cells}

On the functional level, differentiated cells showed greater alkaline phosphatase activity, a marker of enterocyte differentiation, compared with proliferating cells. Interestingly, the activity of alkaline phosphatase was significantly higher in $\mathrm{D}+\mathrm{N} v . \mathrm{D}-\mathrm{N}$ cells (Fig. 3).

\section{Analysis of Rnd3 gene expression in differentiated IEC-6 cells}

The differential display technique had been used to identify genes whose expression was regulated during enterocyte differentiation. Results obtained showed that Rnd3 mRNA levels were lower in differentiated than in proliferating IEC6 cells $^{36}$. In the present study, addition of NS accelerated the reduction in Rnd3 mRNA levels in $\mathrm{D}+\mathrm{N} v . \mathrm{D}-\mathrm{N}$ cells (Fig. 4).

\section{Discussion}

Contradictory reports have been published on the effect of NT or NS on the proliferation and differentiation of intestinal cells, probably due to differences in experimental approach, including the use of different mixtures of nucleot(s)ides at varying concentrations, and to the use of distinct cancer cell lines (Caco-2, HT-29) ${ }^{13-17}$. Cancer cell lines are known to have higher rates of de novo NS synthesis than normal cells. To avoid the interference of cell transformation, the effect of NS on cell differentiation was studied in IEC-6 cells because it is a non-transformed intestinal cell line that undergoes differentiation when grown on an extracellular protein matrix. The only published report on the effect of NT on IEC-6 cell differentiation showed that addition of NT enhanced proliferation but not differentiation, as assessed by alkaline phosphatase and sucrose-isomaltase activities ${ }^{14}$. However, some aspects of the latter study can be questioned. First, NT rather than NS were used, and the high level of alkaline phosphatase activity in mature intestine is known to degrade NT to phosphate and NS that enter cells via specific transporters ${ }^{23}$. Second, the possibility of a hormonal effect due to adenosine generation in the culture media cannot be ruled out. For these reasons, IEC- 6 cells were grown in the presence or absence of an inosine-guanosine-cytidine-uridine supplement at physiologic levels $(30 \mu \mathrm{M}$ each, a concentration selected to match NS concentrations in human milk, which range from 0.5 to $37 \mu \mathrm{M})^{18}$. Finally, Sterling \& Cutroneo $^{24}$ detected no sucrase-isomaltase activity in differentiated IEC6 cells, consistent with the present study, in which no expression of the sucrose-isomaltase gene was detected by reverse transcription-PCR in these cells.

According to the present findings, proliferating and differentiated IEC-6 cells control the selective uptake of NS (Table 1). Our group recently reported that hepatocytes ${ }^{10,11}$ and intestinal explants ${ }^{12}$ are capable of selective NS uptake. The present results showed that the rate of uridine and purine NS clearance in IEC-6 cells was similar to that of adult hepatocytes ${ }^{10}$ and of intestinal explants ${ }^{12}$. IEC- 6 cells took up uridine, guanosine and inosine, up to 32, 63 and $100 \%$ in proliferating cells, and 31, 80 and $94 \%$ in differentiated cells, respectively. To date, three $\mathrm{Na}^{+}$-dependent concentrative and two $\mathrm{Na}^{+}$-independent equilibrative transporters have been identified ${ }^{25}$. In IEC-6 cells, Aymerich et $a .^{26}$ showed that these cells express high levels of equilibrative NS transporters (with low substrate selectivity) and of the concentrative NS transporter CNT2 (highly selective for purine NS and uridine). Differentiated IEC-6 cells mainly express CNT2 and, slightly, CNT1 (selective for pyrimidine NS and adenosine) with a decrease in the activity of equilibrative transporters. The apparent $K_{m}$ values for rat CNT2-mediated transport of uridine, guanosine and inosine are 24,34 and $12 \mu \mathrm{M}$, respectively ${ }^{27}$. We suggest that the predominance of CNT2 transporter activity would explain the preferential clearance of the former NS by proliferating and differentiated IEC- 6 cells.

Concerning cytidine, Ohyanagi et al. ${ }^{28}$ and Arnaud et al. ${ }^{10}$ observed that hepatocytes hardly took up cytidine. In the present study and in intestinal explants ${ }^{12}$, there was an efflux of cytidine to the culture medium. The apparent $K_{m}$ for rat CNT2-mediated transport of cytidine is $505 \mu \mathrm{M}, 16 \cdot 8$ fold higher than its initial concentration in culture media. Therefore, cytidine would be poorly transported by CNT2 into IEC-6 cells. The results suggest that de novo synthesis and salvage of uridine by uridine kinase is preferentially used to meet intracellular pyrimidine NT needs. Cells produce cytidine, in the form of CTP, from UTP by cytidine triphosphate synthetase, using ATP and glutamine. The increase of cytidine in culture media may be the result of cytidine export due to excessive biosynthesis from UTP.

The present study is the first report on the effect of exogenous NS on the intracellular NT pool in differentiated intestinal 
Table 2. Intracellular nucleotide concentrations in proliferating and differentiated IEC-6 cells cultured in the presence or absence of a nucleoside supplement†

(Mean values with their standard errors for three determinations)

\begin{tabular}{|c|c|c|c|c|c|c|c|c|c|c|c|c|c|c|c|c|}
\hline & \multicolumn{4}{|c|}{$\mathrm{P}-\mathrm{N}\left(\mathrm{nmol} / 10^{6}\right.$ cells $)$} & \multicolumn{4}{|c|}{$\mathrm{P}+\mathrm{N}\left(\mathrm{nmol} / 10^{6}\right.$ cells $)$} & \multicolumn{4}{|c|}{$\mathrm{D}-\mathrm{N}\left(\mathrm{nmol} / 10^{6}\right.$ cells $)$} & \multicolumn{4}{|c|}{$\mathrm{D}+\mathrm{N}\left(\mathrm{nmol} / 10^{6}\right.$ cells $)$} \\
\hline & \multicolumn{2}{|c|}{$12 \mathrm{~h}$} & \multicolumn{2}{|c|}{$24 \mathrm{~h}$} & \multicolumn{2}{|c|}{$12 \mathrm{~h}$} & \multicolumn{2}{|c|}{$24 \mathrm{~h}$} & \multicolumn{2}{|c|}{$12 \mathrm{~h}$} & \multicolumn{2}{|c|}{$24 \mathrm{~h}$} & \multicolumn{2}{|c|}{$12 \mathrm{~h}$} & \multicolumn{2}{|c|}{$24 \mathrm{~h}$} \\
\hline & Mean & SE & Mean & SE & Mean & SE & Mean & SE & Mean & SE & Mean & SE & Mean & SE & Mean & $\mathrm{SE}$ \\
\hline CDP-choline & $3 \cdot 2^{\mathrm{c}}$ & 0.2 & - & - & $4 \cdot 7^{\mathrm{ab}}$ & 0.3 & $1.4^{\mathrm{e}}$ & 0.2 & $2 \cdot 1^{\mathrm{d}}$ & 0.1 & $4.0^{\mathrm{b}}$ & 0.3 & $5 \cdot 3^{\mathrm{a}}$ & 0.2 & $5 \cdot 0^{\mathrm{a}}$ & 0.3 \\
\hline CMP & $5 \cdot 8^{\mathrm{b}}$ & 0.5 & $1.7^{\mathrm{d}}$ & 0.4 & $10.5^{\mathrm{a}}$ & 0.6 & $4 \cdot 6^{\mathrm{c}}$ & 0.5 & $2 \cdot 4^{\mathrm{d}}$ & 0.4 & $4 \cdot 6^{\mathrm{c}}$ & 0.4 & $4 \cdot 9^{\mathrm{bc}}$ & 0.6 & $2 \cdot 3^{\mathrm{d}}$ & 0.3 \\
\hline CDP & $2 \cdot 7^{\mathrm{e}}$ & 0.5 & - & - & - & - & - & - & $45 \cdot 7^{\mathrm{C}}$ & 3.6 & $75 \cdot 5^{\mathrm{b}}$ & $6 \cdot 1$ & $97 \cdot 9^{\mathrm{a}}$ & 6.4 & $101 \cdot 0^{\mathrm{a}}$ & 3.9 \\
\hline CTP & $8.6^{\mathrm{C}}$ & 0.4 & $0.6^{f}$ & 0.1 & $10.4^{\mathrm{b}}$ & 0.8 & $3.1^{\mathrm{e}}$ & 0.4 & $5 \cdot 9^{\mathrm{d}}$ & 0.5 & $13 \cdot 2^{\mathrm{a}}$ & $2 \cdot 6$ & $14.5^{\mathrm{a}}$ & 2.6 & $13 \cdot 6^{\mathrm{a}}$ & 1.6 \\
\hline $\begin{array}{r}\text { Total cytosine } \\
\text { nucleotides }\end{array}$ & $20 \cdot 3^{\mathrm{d}}$ & $2 \cdot 5$ & $2 \cdot 3^{t}$ & 0.5 & $25 \cdot 6^{d}$ & 2.9 & $9 \cdot 1^{\mathrm{e}}$ & $1 \cdot 0$ & $56 \cdot 1^{\mathrm{C}}$ & $4 \cdot 6$ & $97 \cdot 3^{\mathrm{b}}$ & $8 \cdot 8$ & $122 \cdot 6^{\mathrm{a}}$ & 9.5 & $121 \cdot 9^{\mathrm{a}}$ & $10 \cdot 3$ \\
\hline UDP-glucose & $4 \cdot 2^{\mathrm{b}}$ & 0.3 & $1.0^{\mathrm{d}}$ & 0.3 & $6.9^{\mathrm{a}}$ & $1 \cdot 0$ & $3.0^{\mathrm{c}}$ & 0.2 & - & - & - & - & - & - & - & - \\
\hline UMP & $6 \cdot 3^{\mathrm{d}}$ & 0.5 & $1.9^{\mathrm{e}}$ & 0.4 & $14 \cdot 8^{\mathrm{C}}$ & 1.4 & $6.0^{\mathrm{d}}$ & 0.5 & $6.8^{\mathrm{d}}$ & 0.9 & $5 \cdot 8^{\mathrm{d}}$ & 0.6 & $40 \cdot 9^{\mathrm{a}}$ & 3.9 & $33.1^{\mathrm{b}}$ & $4 \cdot 2$ \\
\hline UTP & $14.8^{\mathrm{b}}$ & $2 \cdot 0$ & $4.1^{\mathrm{d}}$ & 0.2 & $25 \cdot 9^{\mathrm{a}}$ & 3.7 & $10 \cdot 3^{\mathrm{c}}$ & 1.3 & $11.0^{\mathrm{C}}$ & 1.8 & $16 \cdot 6^{\mathrm{b}}$ & 2.1 & $30.9^{\mathrm{a}}$ & $3 \cdot 1$ & $30.5^{\mathrm{a}}$ & 3.4 \\
\hline $\begin{array}{l}\text { Total uridine } \\
\text { nucleotides }\end{array}$ & $25 \cdot 2^{\mathrm{c}}$ & $2 \cdot 7$ & $7 \cdot 0^{\mathrm{e}}$ & 0.7 & $47 \cdot 6^{\mathrm{b}}$ & $5 \cdot 8$ & $19 \cdot 4^{\mathrm{C}}$ & 1.6 & $17 \cdot 7^{d}$ & $2 \cdot 6$ & $22 \cdot 4^{\mathrm{cd}}$ & $2 \cdot 1$ & $71 \cdot 8^{\mathrm{a}}$ & $6 \cdot 0$ & $63 \cdot 7^{\mathrm{a}}$ & $6 \cdot 4$ \\
\hline $\mathrm{NAD}^{+}$ & - & - & $0.4^{\mathrm{b}}$ & 0.1 & $1 \cdot 2^{\mathrm{a}}$ & 0.2 & $0.5^{\mathrm{b}}$ & 0.1 & - & - & $1.7^{\mathrm{a}}$ & 0.2 & $1 \cdot 3^{\mathrm{a}}$ & 0.2 & $1.5^{\mathrm{a}}$ & 0.4 \\
\hline AMP & - & - & - & - & - & - & - & - & $5 \cdot 0^{\mathrm{b}}$ & 0.4 & $8.0^{\mathrm{a}}$ & 1.0 & $8.4^{\mathrm{a}}$ & 0.8 & $7.5^{\mathrm{a}}$ & 0.5 \\
\hline ADP & $6.4^{\mathrm{b}}$ & 0.4 & $3.7^{c}$ & 0.3 & $8 \cdot 4^{\mathrm{a}}$ & 0.8 & $4.8^{b c}$ & 0.9 & $5 \cdot 8^{\mathrm{b}}$ & 0.9 & $9.9^{\mathrm{a}}$ & $1 \cdot 2$ & $9 \cdot 2^{\mathrm{a}}$ & 0.3 & $10 \cdot 5^{\mathrm{a}}$ & 1.6 \\
\hline ATP & $10 \cdot 7^{\mathrm{C}}$ & 0.7 & $4 \cdot 2^{\mathrm{d}}$ & 0.9 & $9 \cdot 9^{c}$ & 1.3 & $4 \cdot 2^{d}$ & 0.6 & $20.0^{\mathrm{b}}$ & 3.5 & $32 \cdot 9^{\mathrm{a}}$ & 1.7 & $27 \cdot 8^{\mathrm{a}}$ & 3.3 & $34 \cdot 3^{\mathrm{a}}$ & 3.4 \\
\hline $\begin{array}{r}\text { Total adenine } \\
\text { nucleotides }\end{array}$ & $17 \cdot 1^{\mathrm{c}}$ & $2 \cdot 9$ & $8 \cdot 3^{d}$ & $1 \cdot 2$ & $19 \cdot 5^{\mathrm{C}}$ & 2.5 & $9 \cdot 5^{\mathrm{d}}$ & 1.4 & $30 \cdot 8^{b}$ & 5.4 & $52 \cdot 5^{\mathrm{a}}$ & $6 \cdot 3$ & $46 \cdot 7^{\mathrm{a}}$ & $6 \cdot 4$ & $53 \cdot 9^{\mathrm{a}}$ & $7 \cdot 7$ \\
\hline GMP & $32.6^{\mathrm{e}}$ & 5.8 & $15 \cdot 2^{f}$ & 2.5 & $120 \cdot 3^{b}$ & $11 \cdot 1$ & $38.9^{\mathrm{de}}$ & 4.2 & $47.0^{\mathrm{d}}$ & $7 \cdot 2$ & $65 \cdot 8^{\mathrm{c}}$ & 9.7 & $420 \cdot 3^{a}$ & $42 \cdot 8$ & $428 \cdot 5^{\mathrm{a}}$ & $51 \cdot 2$ \\
\hline GTP & $2 \cdot 2^{f}$ & 0.5 & $2 \cdot 2^{f}$ & 0.4 & $10 \cdot 1^{\mathrm{e}}$ & 1.4 & $2 \cdot 8^{f}$ & 0.6 & $30 \cdot 2^{d}$ & 6.7 & $49 \cdot 4^{\mathrm{C}}$ & $7 \cdot 0$ & $99 \cdot 8^{b}$ & 12.3 & $137.5^{\mathrm{a}}$ & 18.5 \\
\hline $\begin{array}{r}\text { Total guanine } \\
\text { nucleotides }\end{array}$ & $34 \cdot 8^{c}$ & $5 \cdot 1$ & $17 \cdot 4^{\mathrm{d}}$ & 1.8 & $130 \cdot 3^{b}$ & $15 \cdot 7$ & $41 \cdot 7^{\mathrm{C}}$ & 6.6 & $77 \cdot 2^{\mathrm{c}}$ & $3 \cdot 3$ & $115 \cdot 2^{b}$ & 10.6 & $520 \cdot 0^{\mathrm{a}}$ & $51 \cdot 1$ & $565 \cdot 9^{\mathrm{a}}$ & $45 \cdot 4$ \\
\hline TTP & $1.29^{c}$ & 0.1 & $3 \cdot 16^{\mathrm{b}}$ & 0.2 & $1.68^{\mathrm{C}}$ & 0.2 & $4.79^{\mathrm{a}}$ & 0.7 & - & - & - & - & - & - & - & - \\
\hline IMP & - & - & - & - & - & - & - & - & - & - & - & - & $9 \cdot 6^{\mathrm{b}}$ & 1.9 & $14 \cdot 0^{\mathrm{a}}$ & 1.8 \\
\hline
\end{tabular}

CDP-choline, cytidine diphosphocholine; $\mathrm{D}-\mathrm{N}$, differentiated cells; $\mathrm{D}+\mathrm{N}$, differentiated cells grown with nucleosides; $\mathrm{P}-\mathrm{N}$, proliferating cells; $\mathrm{P}+\mathrm{N}$, proliferating cells grown with nucleosides; UDP-glucose, uridine diphosphoglucose.

†Proliferating and differentiated IEC- 6 cells were cultured in the presence or absence of a nucleoside supplement: uridine, cytidine, guanosine and inosine ( $30 \mu \mathrm{M}$ each).

${ }_{\mathrm{a}-\mathrm{f}}$ Mean values within a row with unlike superscript letters were significantly different $(P<0.05)$

cells (Table 2). It is worth noting that the total intracellular NT pool was significantly higher in differentiated cells than in proliferating ones $(\mathrm{D}-\mathrm{N} v . \mathrm{P}-\mathrm{N})$. A similar result was observed in differentiated Caco-2 cells ${ }^{14}$, and it was concluded that differentiation may activate NT biosynthesis in intestinal cells. Analysis of the intracellular NT pool in IEC-6 cells showed that differentiated cells had no detectable intracellular thymidine NT compared to proliferating ones, probably related to the arrest of cell division.

Exogenous NS significantly altered the concentration and distribution of soluble intracellular NT. Incubation of IEC-6 cells with NS produced an increase in intracellular NT concentrations of proliferating $(\mathrm{P}+\mathrm{N} v . \mathrm{P}-\mathrm{N})$ and differentiated

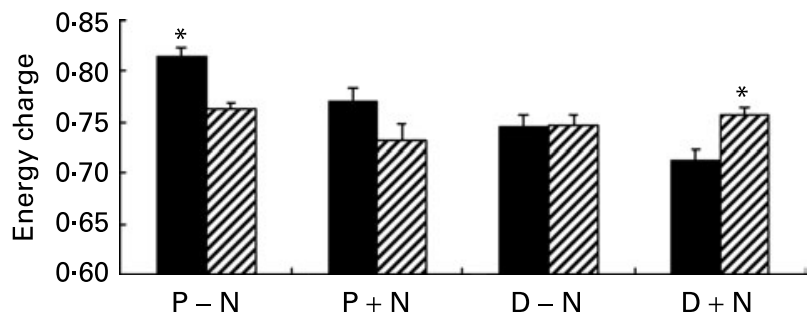

Fig. 2. Energy charge values in proliferating $(P)$ and differentiated (D) IEC-6 cells cultured with $(+N)$ or without nucleosides $(-N)$ at $12 \mathrm{~h}(\square)$ and $24 \mathrm{~h}$ $(\mathbb{Q})$. Cell media was supplemented with uridine, cytidine, guanosine and inosine $(30 \mu \mathrm{m}$ each). Values are means with their standard errors depicted by vertical bars for three calculations per group. ${ }^{*}$ Significant effect of time, $P<0.05$.
$(\mathrm{D}+\mathrm{N} v . \mathrm{D}-\mathrm{N})$ cells. This result agrees with the work of many authors in primary cells or cell lines ${ }^{13-17,29-32}$. We believe that salvage of NS contributed to de novo synthesis, thereby increasing the intracellular NT pool. Uptake and salvage of guanosine and inosine significantly increased the intracellular pool of guanosine NT rather than adenosine derivatives. Total guanosine NT, which play an important role in GTPase-mediated cell structure organization and signalling as well as in protein synthesis ${ }^{33,34}$, increased $2 \cdot 5$-fold in $\mathrm{P}+\mathrm{N}$ cells and 5-fold in $\mathrm{D}+\mathrm{N}$ cells with respect to unsupplemented counterparts. The detection of intracellular IMP may indicate that the synthesis of purine NT was saturated in differentiated cells supplemented with exogenous NS $(D+N)$. Indeed, the highest concentrations of intracellular purine NT were reached in these cells. The present data

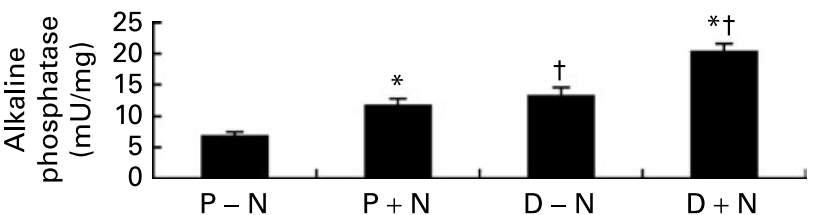

Fig. 3. Alkaline phosphatase activities in proliferating $(P)$ and differentiated (D) IEC-6 cells cultured with $(+N)$ or without nucleosides $(-N)$. Cell media was supplemented with uridine, cytidine, guanosine and inosine $(30 \mu \mathrm{M}$ each). Values are means with their standard errors depicted by vertical bars for three determinations per group. *Significant effect of nucleoside supplementation, $P<0.05$. $†$ Significant effect of cell state, $P<0.05$. 


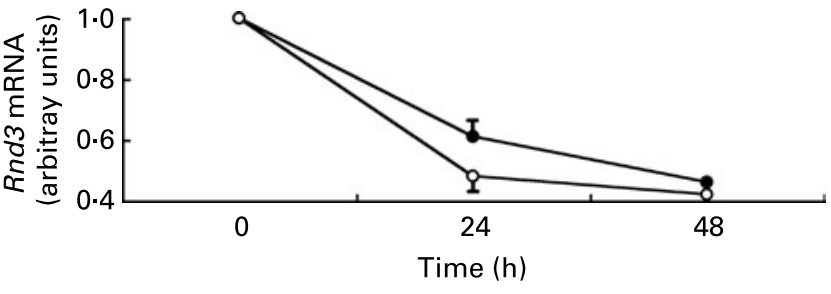

Fig. 4. Effect of nucleoside supplementation on the levels of Rnd3 mRNA in differentiated IEC-6 cells. Cells were cultured with $(O)$ or without $(\bullet)$ uridine, cytidine, guanosine and inosine ( $30 \mathrm{~mm}$ each). mRNA levels were analysed by Northern blot and normalized to the expression of glyceraldehyde-3-phosphate dehydrogenase. Values are means with their standard errors depicted by vertical bars for three determinations per group. The mean of undifferentiated cells (time $0 \mathrm{~h}$ ) was set to 1 .

showed that intracellular ATP and $\mathrm{NAD}^{+}$concentrations are tightly controlled in IEC-6 cells. Although exogenous NS modified $\mathrm{NAD}^{+}$and adenosine NT values, the amount of total adenine NT and ATP levels were significantly different only at $12 \mathrm{~h}$ in $\mathrm{D}+\mathrm{N}$ cells compared with $\mathrm{D}-\mathrm{N}$ cells. These data contrasted with the energy charge values that were significantly higher in $\mathrm{D}+\mathrm{N}$ than in $\mathrm{D}-\mathrm{N}$ cells at $24 \mathrm{~h}$ (Fig. 2), and suggested that energy was more efficiently stored in NS-supplemented differentiated IEC-6 cells. It is noteworthy that uric acid was not detected in culture media although intestinal cells express xanthine oxidase. The result indicated that purine NS were incorporated into the intracellular NT pool rather than being catabolized to uric acid.

In parallel, we observed that exogenous NS enhanced the differentiation of IEC-6 cells. Morphologically, microvilli were more abundant in $\mathrm{D}+\mathrm{N}$ cells and persisted longer than in $\mathrm{D}-\mathrm{N}$ cells (Fig. 1). Moreover, at the enzymatic level, $\mathrm{D}+\mathrm{N}$ cells had higher alkaline phosphatase activity $\mathrm{D}-\mathrm{N}$ cells (Fig. 3). The present results agree with those of Sato et al. $^{35}$, who observed that NS supplementation promoted the formation of tight junctions, the expression of microvilli, and the activities of maltase and sucrase-isomaltase. Concerning gene expression, we used the differential display technique to identify genes regulated during the initial stages of enterocyte differentiation. One of these differentiation-regulated genes was $R n d 3^{36}$, a member of the Rho family of small GTPases involved in cytoskeleton arrangements ${ }^{33}$. Northern blot analyses showed that Rnd3 mRNA levels significantly diminished during IEC-6 differentiation. We are aware that, although statistically modest, the present results showed that NS supplementation accelerated the changes in Rnd3 mRNA levels during enterocyte differentiation (Fig. 4).

In conclusion, exogenous NS were selectively taken up by IEC-6 cells and increased the intracellular NT pool in proliferating and differentiated cells. Because de novo synthesis of NT is an energy-intensive process, cells fulfil their NT requirements by NS salvage that spares energy and intermediary metabolites. The increase in energy charge and intracellular GTP concentrations in differentiated cells may favour the turnover of proteins and nucleic acids required for the transition from the proliferative to differentiation state in IEC-6 cells. These changes associated with an enhanced maturation of intestinal cells, improving their differentiation at morphological, functional and gene expression levels. The present findings agree with the work of many authors in cells and animal models of injury ${ }^{2-9,37-39}$, and provide new evidence of the beneficial effect of exogenous NS on the functionality of intestinal epithelial cells.

\section{Acknowledgements}

This work was financed by Spanish Science Ministry Research Project PM97-0171 and by ABBOTT research project 71400. Raul de la Torre was the recipient of a Junta de Andalucia predoctoral fellowship.

\section{References}

1. Schlimme E, Martin D \& Meisel H (2000) Nucleosides and nucleotides: natural bioactive substances in milk and colostrum. Br J Nutr 84, Suppl. 1, S59-S68.

2. Sánchez-Pozo A \& Gil A (2002) Nucleotides as semiessential nutritional components. Br J Nutr 87, Suppl. 1, S135-S137.

3. Gil A (2002) Modulation of the immune response mediated by dietary nucleotides. Eur J Clin Nutr 56, Suppl. 3, S1-S4.

4. Evans ME, Jones DP \& Ziegler TR (2005) Glutamine inhibits cytokine-induced apoptosis in human colonic epithelial cells via the pyrimidine pathway. Am J Physiol Gastrointest Liver Physiol 289, G388-G396.

5. Nunez MC, Bueno JD, Ayudarte MV, Almendros A, Rios A, Suarez MD \& Gil A (1996) Dietary restriction induces biochemical and morphometric changes in the small intestine of nursing piglets. J Nutr 126, 933-944.

6. Arnaud A, Lopez-Pedrosa JM, Torres MI \& Gil A (2003) Dietary nucleotides modulate mitochondrial function of intestinal mucosa in weanling rats with chronic diarrhea. J Pediatr Gastroenterol Nutr 37, 124-131.

7. Mabley JG, Pacher P, Liaudet L, Soriano FG, Hasko G, Marton A, Szabo C \& Salzman AL (2003) Inosine reduces inflammation and improves survival in a murine model of colitis. Am J Physiol-Gastrointest Liver Physiol 284, G138-G144.

8. Dowdall JF, Winter DC \& Bouchier-Hayes DJ (2002) Inosine modulates gut barrier dysfunction and end organ damage in a model of ischemia-reperfusion injury. J Surg Res 108, 61-68.

9. Belo A, Marchbank T, Fitzgerald A, Ghosh S \& Playford RJ (2006) Gastroprotective effects of oral nucleotide administration. Gut 55, 165-171.

10. Arnaud A, Fontana L, Angulo AJ, Gil A \& Lopez-Pedrosa JM (2003) Exogenous nucleosides alter the intracellular nucleotide pool in hepatic cell cultures. Implications in cell proliferation and function. Clin Nutr 22, 391-399.

11. Saez-Lara MJ, Manzano M, Angulo AJ, Suarez A, Torres MI, Gomez-Llorente C, Gil A \& Fontana L (2004) Exogenous nucleosides stimulate proliferation of fetal rat hepatocytes. J Nutr 134, 1309-1313.

12. Gil A, Gómez-León C \& Rueda R (2007) Exogenous nucleic acids and nucleotides are efficiently hydrolysed and taken up as nucleosides by intestinal explants from suckling piglets. Br J Nutr 98, 285-291.

13. Sato N, Nakano T, Kawakami H \& Idota T (1999) In vitro and in vivo effects of exogenous nucleotides on the proliferation and maturation of intestinal epithelial cells. J Nutr Sci Vitaminol (Tokyo) 45, 107-118.

14. He Y, Chu SH \& Walker WA (1993) Nucleotide supplements alter proliferation and differentiation of cultured human (Caco-2) and rat (IEC-6) intestinal epithelial cells. J Nutr 123, 1017-1027.

15. Boza JJ, Moennoz D, Bournot CE, Blum S, Zbinden I, Finot PA \& Ballevre O (2000) Role of glutamine on the de novo purine nucleotide synthesis in Caco-2 cells. Eur J Nutr 39, 38-46. 
16. Tanaka M, Lee K, Martinez-Augustin O, He Y, Sanderson IR \& Walker WA (1996) Exogenous nucleotides alter the proliferation, differentiation and apoptosis of human small intestinal epithelium. J Nutr 126, 424-433.

17. Chen X, Wang R, Deng M \& Ran X (2001) Effects of exogenous adenosine $5^{\prime}$-monophosphate on proliferation and apoptosis of small intestinal epithelial cells. Wei Sheng Yan Jiu 30, $165-167$.

18. Duchen K \& Thorell L (1999) Nucleotide and polyamine levels in colostrum and mature milk in relation to maternal atopy and atopic development in the children. Acta Paediatr 88, $1338-1343$.

19. Gehrke C \& Kuo K (editors) (1990) Chromatography and Modification of Nucleosides, Part A, B and C Analytical Methods for Major and Modified Nucleosides HPLC, GC, MS, NMR and FT-IR. Amsterdam: Elsevier.

20. Perret D (1993) Nucleotides, nucleosides and bases. In High Performance Liquid Chromatography in Neuroscience Research, pp. 163-165 [RB Holman, AJ Cross and MH Joseph, editors]. London: Wiley.

21. Goldstein R, Klein T, Freier S \& Menczel J (1971) Alkaline phosphatase and dissaccharidase activities in the rat intestine from birth to weaning. I. Effect of diet on enzyme development. Am J Clin Nutr 24, 1224-1231.

22. Brown RE, Jarvis KL \& Hyland KJ (1989) Protein measurement using bicinchoninic acid: elimination of interfering substances. Anal Biochem 180, 136-139.

23. Aymerich I, Pastor-Anglada M \& Casado FJ (2004) Long term endocrine regulation of nucleoside transporters in rat intestinal epithelial cells. J Gen Physiol 124, 505-512.

24. Sterling KM Jr \& Cutroneo KR (2002) Differentiation-dependent induction of CYP1A1 in cultured rat small intestinal epithelial cells, colonocytes, and human colon carcinoma cells: basement membrane-mediated apoptosis. J Cell Biochem 86, 440-450.

25. Aymerich I, Duflot S, Fernandez-Veledo S, Guillen-Gomez E, Huber-Ruano I, Casado FJ \& Pastor-Anglada M (2005) The concentrative nucleoside transporter family (SLC28): new roles beyond salvage? Biochem Soc Trans 33, 216-219.

26. Aymerich I, Foufelle F, Ferre P, Casado FJ \& Pastor-Anglada M (2006) Extracellular adenosine activates AMP-dependent protein kinase (AMPK). J Cell Sci 119, 1612-1621.

27. Larrayoz IM, Fernandez-Nistal A, Garces A, Gorraitz E \& Lostao MP (2006) Characterization of the rat $\mathrm{Na}^{+} /$nucleoside cotransporter 2 and transport of nucleoside-derived drugs using electrophysiological methods. Am J Physiol Cell Physiol 291, C1395-C1404.

28. Ohyanagi H, Nishimatsu S, Kanbara Y, Usami M \& Saitoh Y (1989) Effects of nucleosides and a nucleotide on DNA and RNA syntheses by the salvage and de novo pathway in primary monolayer cultures of hepatocytes and hepatoma cells. JPEN $J$ Parenter Enteral Nutr 13, 51-58.

29. Mayer D, Natsumeda Y, Ikegami T, Faderan M, Lui M, Emrani J, Reardon M, Olah E \& Weber G (1990) Expression of key enzymes of purine and pyrimidine metabolism in a hepatocyte-derived cell line at different phases of the growth cycle. J Cancer Res Clin Oncol 116, 251-258.

30. Moyer JD, Oliver JT \& Handschumacher RE (1981) Salvage of circulating pyrimidine nucleosides in the rat. Cancer Res 41, 3010-3017.

31. Pels Rijcken WR, Overdijk B, Van den Eijnden DH \& Ferwerda W (1995) The effect of increasing nucleotide-sugar concentrations on the incorporation of sugars into glycoconjugates in rat hepatocytes. Biochem J 305, 865-870.

32. Karle JM, Anderson LW \& Cysyk RL (1984) Effect of plasma concentrations of uridine on pyrimidine biosynthesis in cultured L1210 cells. J Biol Chem 259, 67-72.

33. Hallett MA, Dagher PC \& Atkinson SJ (2003) Rho GTPases show differential sensitivity to nucleotide triphophate depletion in a model of ischemic cell injury. Am J Physiol Cell Physiol 285, C129-C138.

34. Hucul JA, Henshaw EC \& Young DA (1985) Nucleoside diphosphate regulation of overall rates of protein biosynthesis acting at the level of initiation. J Biol Chem 260, 15585-15591.

35. Sato N, Kawakami H \& Idota A (2000) Nucleotide and nucleoside supplementation may morphologically promote the differentiation of human caco-2 cells. J Nutr Sci Vitaminol (Tokyo) 46, 175-179.

36. Vieites JM, Sanchez-Pozo A, Gil A \& Suarez A (2005) Development of a protocol for the analysis of genetic expression by differential display. Ars Pharm 46, 193-204.

37. Perez MJ, Suarez A, Gomez-Capilla JA, Sanchez-Medina F \& Gil A (2002) Dietary nucleotide supplementation reduces thioacetamide-induced liver fibrosis in rats. $J$ Nutr 132, 652-657.

38. Perez MJ, Sanchez-Medina F, Torres M, Gil A \& Suarez A (2004) Dietary nucleotides enhance the liver redox state and protein synthesis in cirrhotic rats. J Nutr 134, 2504-2508.

39. Grimble GK (1994) Dietary nucleotides and gut mucosal defence. Gut 35, S46-S51. 